\title{
Clinical Impact of Circulating Tumor Cells in Patients with Localized Prostate Cancer
}

\author{
Lucile Broncy ${ }^{1}$ and Patrizia Paterlini-Bréchot $1,2, *$ (D) \\ 1 INSERM Unit 1151, Faculté de Médecine, Université Paris Descartes, 75014 Paris, France \\ 2 Laboratoire de Biochimie A, Hôpital Necker-Enfants Malades, 75015 Paris, France \\ * Correspondence: patrizia.paterlini@inserm.fr; Tel.: +33-172-606-462
}

Received: 3 June 2019; Accepted: 1 July 2019; Published: 3 July 2019

\begin{abstract}
The main issue concerning localized prostate cancers is the lack of a suitable marker which could help patients' stratification at diagnosis and distinguish those with a benign disease from patients with a more aggressive cancer. Circulating Tumor Cells (CTC) are spread in the blood by invasive tumors and could be the ideal marker in this setting. Therefore, we have compiled data from the literature in order to obtain clues about the clinical impact of CTC in patients with localized prostate cancer. Forty-three publications have been found reporting analyses of CTC in patients with non-metastatic prostate cancer. Of these, we have made a further selection of 11 studies targeting patients with clinical or pathological stages T1 and T2 and reporting the clinical impact of CTC. The results of this search show encouraging data toward the use of CTC in patients with early-stage cancer. However, they also highlight the lack of standardized methods providing a highly sensitive and specific approach for the detection of prostate-derived CTC.
\end{abstract}

Keywords: prostate cancer (PCa); circulating tumor cells (CTC); liquid biopsy

\section{Introduction}

Globally, prostate cancer (PCa) is the most commonly diagnosed type of cancer in men, with 180,890 newly diagnosed cases and 26,120 deaths in the United States (US) in 2016 [1] and estimated 164,690 new cases and 29,430 deaths in 2018 [2]. As the fifth leading cause of cancer death worldwide, PCa accounted globally for 1.6 million newly diagnosed cases and 366,000 deaths in 2015 [1]. Increased risk factors for PCa include genetic predisposition, family history of prostate or breast cancers and older age, with a median age at diagnosis of 72 years [3]. Accordingly, the steady increase in PCa incidence in the US since 1950 appears related to an overall increase in life expectancy. In the US, the lifetime risk of being diagnosed with prostate cancer is of $11 \%$ and the lifetime risk of dying of prostate cancer is $2.5 \%$ [4]. Importantly, in autopsies of men who died of other causes, more than $20 \%$ of men aged 50 to 59 years and over $33 \%$ of men aged 70 to 79 years were found to have prostate cancer [5]. At diagnosis, $79 \%$ of prostate cancer cases were localized; in $12 \%$, the cancer had spread to regional lymph nodes, and $5 \%$ of patients had distant metastasis. The 5-year relative survival rate for localized and regional prostate cancer is $100 \%$, compared with $29.8 \%$ for metastatic cases.

PCa is recognized as a genetically heterogeneous disease [6] comprising a large scope of malignancies, from indolent localized cancers that may never progress to rapidly progressing castration-resistant PCa. Currently, the diagnosis of PCa is based on the pathological evaluation of tissue biopsy but the treatment options are determined by risk stratification based on both Gleason score and serum PSA level [7]. For example, high-risk PCa was defined by D'Amico as PSA $\geq 20 \mathrm{ng} / \mathrm{mL}$ and/or biopsy Gleason Score $\geq 8$ and/or clinical stage $\geq 2 \mathrm{c}$ [8].

Elevated serum prostate-specific antigen (PSA) levels are often seen in the context of PCa but can also reflect other prostatic diseases such as benign prostatic hyperplasia, prostatic infection, and 
prostatic infarction [9]. Relatedly, the low specificity of the PSA screening test has raised concerns in the scientific community regarding the over-diagnosis of PCa [10]. Since the implementation of the PSA screening test into clinical practices in the 1990s, a significant shift towards localized PCa at diagnoses has been observed, with $>95 \%$ of diagnoses being of clinically localized PCa [11]. Furthermore, only approximately 40 to $50 \%$ of patients with elevated PSA testing undergoing a biopsy have prostate cancer. However, a recent study evaluating the ERSPC and PLCO clinical trials has shown that PSA testing reduces the mortality due to PCa by approximately 30\% [12]. In cases of localized PCa, radical prostatectomy remains the gold standard treatment option [7]. Importantly, up to $30 \%$ of patients treated with radical prostatectomy eventually develop recurrence [13]. More performant risk stratification and prognostic markers are urgently needed to improve the management of patients with localized prostate cancer and identify cases with a high risk of progression.

Circulating tumor cells (CTC) are cells that detach from the primary or secondary tumor sites and invade the bloodstream. As primary actors of the metastatic dissemination, CTC represent a very promising biomarker to aid cancer diagnosis, treatment decision and patient follow-up [14]. In fact, CTC could provide a valuable complement to PSA or other tests with the aim to identify patients with more aggressive cancers. The prognostic value of CTC collected by the epithelial marker-dependent method CellSearch has been established in the context of metastatic PCa [15]. However, the clinical utility of CTC in the context of localized PCa remains unclear. Here, we review studies on non-metastatic prostate cancer to evaluate the potential clinical utility of CTC in localized PCa.

\section{Materials and Methods}

The present review was prepared by selecting English-written research papers describing the detection and/or characterization of circulating tumor cells in the context of localized prostate cancer. To that end, we searched PubMed using the following keywords: "circulating tumor cells" or "circulating cancer cells" and "localized prostate cancer" or "non-metastatic prostate cancer" or "early-stage prostatic carcinoma". Reviews and studies on liquid biopsy that did not concern localized PCa, as well as studies that did not report on CTC were excluded from the systematic review. Preclinical models, as well as methods for detection of disseminated tumor cells (DTC) in the bone marrow of localized PCa patients, were also excluded. A total of 43 studies were included in the systematic review, as shown in Table 1. It should be noted that several selected studies also reported on locally advanced prostate cancer (T3 and T4) cases. The American Cancer Society defines localized PCa as clinical or pathological tumor stages T1 and T2. PCa with the T1 stage corresponds to a clinically unapparent tumor that is neither palpable nor visible by imaging while $\mathrm{T} 2$ corresponds to a tumor that is confined within the prostate and that is either palpable or visible by imaging or demonstrated in radical prostatectomy [16]. In contrast, a pathological tumor stage T3 defines a tumor that has extended through the prostatic capsule and T4 defines a tumor which is invading adjacent organs such as the bladder, sphincter or rectum [16]. 
Table 1. Studies on circulating tumor cells in patients with non-metastatic prostate cancer.

\begin{tabular}{|c|c|c|c|c|c|c|c|}
\hline Study [ref] & $\begin{array}{l}\mathbf{N}^{\circ} \text { of Patients } \\
\text { (pT Stage) }\end{array}$ & CTC Method & Cutoff & $\begin{array}{l}\mathbf{N}^{\circ} \text { of CTC+ } \\
\text { Patients (\%) }\end{array}$ & $\begin{array}{c}\text { Median CTC/mL } \\
\text { (Range/mL) }\end{array}$ & Comments & $\begin{array}{c}\text { Clinical } \\
\text { Impact of CTC }\end{array}$ \\
\hline Moreno 1992 [17] & $4\left(\mathrm{ND}^{1}\right)$ & PSA RT-PCR & $\mathrm{NA}^{2}$ & $0(0 \%)$ & NA & $\begin{array}{l}17 \text { negative controls ( } 0 \% \text { positive). Only } \\
\text { patients with lymph nodes or metastases } \\
\text { tested positive. }\end{array}$ & ND \\
\hline Israeli 1995 [18] & $13(7 \mathrm{~T} 2,5 \mathrm{~T} 3,1 \mathrm{~T} 4)$ & $\begin{array}{l}\text { PSA \& PSMA } \\
\text { RT-PCR }\end{array}$ & NA & $\begin{array}{l}\text { PSMA } 7(54 \%) \\
\text { PSA } 0(0 \%)\end{array}$ & NA & $\begin{array}{l}6 \text { years after radical prostatectomy, with } \\
\text { undetectable PSA serum levels, patients are } \\
\text { PSMA positive }\end{array}$ & ND \\
\hline Olsson 1996 [19] & $\begin{array}{c}100(59 \\
\text { T1-T2, } 41 \text { T3-T4 }\end{array}$ & PSA RT-PCR & NA & $\begin{array}{c}74 \%(76 \% \mathrm{~T} 1-\mathrm{T} 2 \\
71 \% \mathrm{~T} 3-\mathrm{T} 4)\end{array}$ & NA & $\begin{array}{l}\text { Potential surgical failure defined as a tumor at } \\
\text { the surgical margin or extending into the } \\
\text { seminal vesicle }\end{array}$ & Yes \\
\hline Ennis 1997 [20] & $\begin{array}{c}227(72 \mathrm{~T} 1 \mathrm{c}, 129 \mathrm{~T} 2 \\
26 \mathrm{~T} 3)\end{array}$ & PSA RT-PCR & NA & $61(26.9 \%)$ & NA & $\begin{array}{l}\text { Patients treated with prostatectomy had a } \\
\text { higher rate of RT-PCR positivity than patients } \\
\text { treated with radiation }\end{array}$ & Yes \\
\hline Oefelein 1999 [21] & $\begin{array}{c}101 \\
(\mathrm{~T} 1-\mathrm{T} 3 \mathrm{a})\end{array}$ & PSA RT-PCR & NA & $22(22 \%)$ & NA & Median follow-up 22 months & No \\
\hline Okegawa 1999 [22] & $\begin{array}{c}31 \\
(\mathrm{~T} 2-\mathrm{T} 3)\end{array}$ & $\begin{array}{l}\text { PSA \& PSMA } \\
\text { RT-PCR }\end{array}$ & NA & ND & NA & $\begin{array}{l}\text { RT-PCR performed before radical } \\
\text { prostatectomy }\end{array}$ & Yes \\
\hline Sabile 1999 [23] & $10(\mathrm{ND})$ & PSA RT-PCR & NA & $4(40 \%)$ & NA & $\begin{array}{c}\text { Density gradient has higher isolation efficiency } \\
\text { than epithelial marker-dependent } \\
\text { immunocapture }\end{array}$ & ND \\
\hline Mejean 2000 [24] & $\begin{array}{c}99(37 \mathrm{~T} 1,52 \mathrm{~T} 2,8 \\
\mathrm{T} 3,2 \mathrm{~T} 4)\end{array}$ & PSA RT-PCR & NA & $33(33 \%)$ & NA & $\begin{array}{l}\text { RT-PCR performed preoperatively, } 92 \text { controls } \\
\text { included ( } 2 \% \text { scored positive) }\end{array}$ & Yes \\
\hline Llanes 2000 [25] & $\begin{array}{c}25 \\
(\mathrm{~T} 1-\mathrm{T} 2 \mathrm{~b})\end{array}$ & PSA RT-PCR & NA & $7(28 \%)$ & NA & $\begin{array}{l}\text { The best predictors of extraprostatic disease } \\
\text { were the biopsy Gleason score and the PSA } \\
\text { level. }\end{array}$ & No \\
\hline Slawin 2000 [26] & $\begin{array}{l}228(154 \mathrm{~T} 1-\mathrm{T} 2,47 \\
\text { T3a, } 16 \mathrm{~T} 3 \mathrm{~b}, 11 \mathrm{~T} 4)\end{array}$ & hK2 RT-PCR & NA & $57(25 \%)$ & NA & $\begin{array}{l}14 \text { healthy controls ( } 14 \% \text { positive). RT-PCR } \\
\text { performed before prostatectomy. Association } \\
\text { with the risk of metastasis to pelvic lymph } \\
\text { nodes }(P=0.028) \text {. }\end{array}$ & Yes \\
\hline Shariat 2002 [27] & $\begin{array}{c}224 \\
(\mathrm{~T} 1-\mathrm{T} 2)\end{array}$ & PSA RT-PCR & NA & $54(24 \%)$ & NA & RT-PCR performed preoperatively. & No \\
\hline Bianco 2002 [28] & $\begin{array}{c}96 \mathrm{AAM} \\
\text { (35 T1, } \\
61 \mathrm{~T} 2) 150 \mathrm{CAM} \\
(62 \mathrm{~T} 1,88 \mathrm{~T} 2)\end{array}$ & PSA RT-PCR & NA & $\begin{array}{l}26(27 \%) \text { AAM } \\
34(23 \%) \text { CAM }\end{array}$ & NA & RT-PCR performed preoperatively. & Yes in AAM \\
\hline Hara 2002 [29] & $\begin{array}{c}44(26 \mathrm{~T} 1,15 \mathrm{~T} 2,2 \\
\mathrm{T} 3,1 \mathrm{~T} 4)\end{array}$ & $\begin{array}{l}\text { PSA, PSMA \& } \\
\text { PSCA RT-PCR }\end{array}$ & NA & $\begin{array}{c}1(2.3 \%) \\
\text { PSA3 (6.8\%) PSMA } \\
1(2.3 \%) \text { PSCA }\end{array}$ & NA & $\begin{array}{l}\text { RT-PCR performed preoperatively. Positive } \\
\text { PSA result in } 1 \text { prostatitis case, positive PSMA } \\
\text { result in } 1 \text { prostatitis and } 1 \text { benign prostatic } \\
\text { hyperplasia case. }\end{array}$ & Yes \\
\hline Thomas 2002 [30] & $\begin{array}{l}141 \text { (118 T1c/T2a, } \\
18 \text { T2b/c, } 5 \text { T3a) }\end{array}$ & $\begin{array}{l}\text { PSA \& PSMA } \\
\text { RT-PCR }\end{array}$ & NA & $73(51.8 \%)$ & NA & $\begin{array}{l}\text { Only initial PSA and } \\
\text { biopsy Gleason score were independent } \\
\text { predictors of biochemical failure. }\end{array}$ & No \\
\hline
\end{tabular}


Table 1. Cont.

\begin{tabular}{|c|c|c|c|c|c|c|c|}
\hline Study [ref] & $\begin{array}{l}\mathbf{N}^{\circ} \text { of Patients } \\
\text { (pT Stage) }\end{array}$ & CTC Method & Cutoff & $\begin{array}{l}\mathbf{N}^{\circ} \text { of CTC+ } \\
\text { Patients (\%) }\end{array}$ & $\begin{array}{l}\text { Median CTC/mL } \\
\text { (Range/mL) }\end{array}$ & Comments & $\begin{array}{c}\text { Clinical } \\
\text { Impact of CTC }\end{array}$ \\
\hline $\begin{array}{c}\text { Gewanter } 2003 \\
\text { [31] }\end{array}$ & $161(121 \mathrm{~T} 1-\mathrm{T} 2,39$ & PSA RT-PCR & NA & $22(20 \%)$ & NA & $\begin{array}{l}29 \text { months follow-up. Only post-treatment } \\
\text { testing predicted for clinical relapse. }\end{array}$ & No \\
\hline Fizazi 2007 [32] & $\begin{array}{c}83(38 \mathrm{~T} 1 \mathrm{c}, 38 \mathrm{~T} 2,7 \\
\mathrm{T} 3)\end{array}$ & $\begin{array}{c}\text { EpCAM + } \\
\text { telomerase PCR }\end{array}$ & NA & $58(70 \%)$ & NA & $\begin{array}{l}\text { Preoperative CTC detection; } 22 \text { healthy } \\
\text { controls ( } 0 \% \text { positive })\end{array}$ & ND \\
\hline Davis 2008 [33] & 97 (78 T2, 19 T3) & CellSearch & $\geq 1 \mathrm{CTC} / 22.5 \mathrm{~mL}$ & $20(21 \%)$ & $0.18(0.04-2.62)$ & $\begin{array}{l}\text { Preoperative CTC detection; } 4 \text { of } 20 \text { healthy } \\
\text { controls positive for CTC }(20 \%)\end{array}$ & ND \\
\hline Helo 2009 [34] & $\begin{array}{l}129(71 \mathrm{~T} 2,43 \mathrm{~T} 3 \mathrm{a} \\
13 \mathrm{~T} 3 \mathrm{~b}, 2 \mathrm{~T} 4)\end{array}$ & $\begin{array}{l}\text { PSA \& PSMA } \\
\text { RT-PCR }\end{array}$ & $\geq 80 \mathrm{mRNA} / \mathrm{mL}$ & $3(2.6 \%)$ & NA & $\begin{array}{l}19 \text { healthy controls ( } 0 \% \text { positive). RT-PCR } \\
\text { performed } 6 \text { months after surgery for } 42 \\
\text { patients and before surgery for } 85 \text { patients }\end{array}$ & No \\
\hline Maestro 2009 [35] & $26(\mathrm{ND})$ & $\begin{array}{l}\text { CellSearch }+ \\
\text { CellSpotter } \\
\text { Analyzer }\end{array}$ & $\geq 2 \mathrm{CTC} / 7.5 \mathrm{~mL}$ & $4(15.4 \%)$ & ND & 106 healthy controls ( $0 \%$ positive) & ND \\
\hline $\begin{array}{c}\text { Eschwe-ge } 2009 \\
\text { [36] }\end{array}$ & $\begin{array}{c}155 \\
(\mathrm{~T} 2-\mathrm{T} 3)\end{array}$ & $\begin{array}{l}\text { PSA \& PSMA } \\
\text { RT-PCR }\end{array}$ & NA & $57(37 \%)$ & NA & $\begin{array}{l}\text { Preoperative CTC detection; } 100 \text { healthy } \\
\text { controls ( } 0 \% \text { positive). }\end{array}$ & Yes \\
\hline Giesing 2010 [37] & $\begin{array}{c}129 \\
(\mathrm{~T} 1-\mathrm{T} 4)\end{array}$ & $\begin{array}{l}\text { Filtration + PSA \& } \\
\text { AOX RT-PCR }\end{array}$ & NA & $42(32.5 \%)$ & NA & $\begin{array}{l}\text { The AOX test was tumour predicting } \\
\text { With a positive predictive value of } \\
69 \% \text { and a negative predictive value of } 92 \% \text {, }\end{array}$ & Yes \\
\hline Stott 2010 [38] & $\begin{array}{c}19 \\
(\mathrm{~T} 2-\mathrm{T} 3 \mathrm{a})\end{array}$ & $\begin{array}{l}\text { Microfluidic } \\
\text { (EpCAM) }\end{array}$ & $\geq 14 \mathrm{CTC} / \mathrm{mL}$ & $8(42 \%)$ & $95(38-222)$ & $\begin{array}{l}\text { 6/8 patients with a decline of CTC } 24 \mathrm{~h} \text { after } \\
\text { prostatectomy }\end{array}$ & ND \\
\hline Joung 2010 [39] & $\begin{array}{l}103(25 \mathrm{~T} 1-\mathrm{T} 2 \mathrm{~b}, 78 \\
\mathrm{T} 2 \mathrm{c}-\mathrm{T} 3)\end{array}$ & PSCA RT-PCR & NA & $17(16.5 \%)$ & NA & RT-PCR performed before surgery & Yes \\
\hline Yates $2012[40]$ & $92(61 \mathrm{~T} 1,31 \mathrm{~T} 2)$ & $\begin{array}{l}\text { PSA \& PSMA } \\
\text { RT-PCR }\end{array}$ & NA & $\begin{array}{c}63(68.5 \%) \text { PSA } \\
68(78.9 \%) \text { PSMA }\end{array}$ & NA & $\begin{array}{l}\text { Blood samples taken } 1 \text { day preoperatively and } \\
7 \text { days postoperatively }\end{array}$ & Yes \\
\hline Lowes 2012 [41] & $26(11 \mathrm{~T} 2,15 \mathrm{~T} 3)$ & CellSearch & $\geq 1 \mathrm{CTC} / 7.5 \mathrm{~mL}$ & $19(73 \%)$ & ND & $\begin{array}{l}\text { Blood drawn before radiation therapy; } 7 \\
\text { healthy controls included ( } 0 \% \text { positive) }\end{array}$ & Yes \\
\hline Khurana 2013 [42] & 10 (5 T2c, 5 T3a) & CellSearch & $\geq 1 \mathrm{CTC} / 7.5 \mathrm{~mL}$ & $1(10 \%)$ & $0(0-0.13)$ & $\begin{array}{c}\text { Blood drawn preoperatively. Very low CTC } \\
\text { numbers. }\end{array}$ & No \\
\hline Thalgott 2013 [43] & $\begin{array}{c}20 \\
(\mathrm{ND})\end{array}$ & CellSearch & $\geq 1 \mathrm{CTC} / 7.5 \mathrm{~mL}$ & $1(5 \%)$ & $0(0-0.13)$ & $\begin{array}{l}15 \text { healthy controls ( } 0 \% \text { positive). Shorter } \\
\text { overall survival observed only for metastatic } \\
\text { patients with } \geq 3 \text { CTC }\end{array}$ & No \\
\hline Loh 2014 [44] & $\begin{array}{c}36(9 \mathrm{~T} 1,14 \mathrm{~T} 2,13 \\
\mathrm{T} 3)\end{array}$ & CellSearch & $\geq 1 \mathrm{CTC} / 7.5 \mathrm{~mL}$ & $5(14 \%)$ & $0(0-0.4)$ & $\begin{array}{l}\text { Blood drawn before therapy. Median } \\
\text { follow-up } 42 \text { months. }\end{array}$ & No \\
\hline $\begin{array}{c}\text { Kolostova } 2014 \\
{[45]}\end{array}$ & $55(45 \mathrm{~T} 2,10 \mathrm{~T} 3)$ & MetaCell@filtration & $\geq 1 \mathrm{CTC} / 8 \mathrm{~mL}$ & $28(52 \%)$ & ND & $\begin{array}{l}\text { CTC were cultured in vitro for downstream } \\
\text { applications for } 7-28 \text { days. The captured } \\
\text { cancer cells displayed plasticity. }\end{array}$ & ND \\
\hline Shao 2014 [46] & $\begin{array}{l}40(26 \mathrm{~T} 2,13 \mathrm{~T} 3,1 \\
\mathrm{Tx})\end{array}$ & $\begin{array}{l}\text { Near-infrared dyes } \\
\quad+\text { FACS }\end{array}$ & $\geq 1 \mathrm{CTC} / 7.5 \mathrm{~mL}$ & $39(97.5 \%)$ & $10(0-439)$ & $\begin{array}{l}\text { Blood samples collected preoperatively. Live } \\
\text { CTC evidenced by staining with heptamethine } \\
\text { carbocyanine dyes }\end{array}$ & No \\
\hline Pal 2015 [47] & $35(32 \mathrm{~T} 1-\mathrm{T} 2,3 \mathrm{~T} 3)$ & CellSearch & $\geq 1 \mathrm{CTC} / 22.5 \mathrm{~mL}$ & $16(45 \%)$ & $0(0-0.1)$ & $\begin{array}{l}\text { Blood samples drawn before and after surgery. } \\
\text { Median follow-up } 510 \text { days. }\end{array}$ & No \\
\hline Thalgott 2015 [48] & $15(1 \mathrm{~T} 2,14 \mathrm{~T} 3)$ & CellSearch & $\geq 1 \mathrm{CTC} / 20 \mathrm{~mL}$ & $3(20 \%)$ & $0(0-0.2)$ & $\begin{array}{l}15 \text { healthy controls ( } 0 \% \text { positive). Median } \\
\text { follow-up } 44.3 \text { months. }\end{array}$ & No \\
\hline
\end{tabular}


Table 1. Cont.

\begin{tabular}{|c|c|c|c|c|c|c|c|}
\hline Study [ref] & $\begin{array}{l}\mathbf{N}^{\circ} \text { of Patients } \\
\text { (pT Stage) }\end{array}$ & CTC Method & Cutoff & $\begin{array}{l}\mathrm{N}^{\circ} \text { of CTC+ } \\
\text { Patients (\%) }\end{array}$ & $\begin{array}{l}\text { Median CTC/mL } \\
\text { (Range/mL) }\end{array}$ & Comments & $\begin{array}{c}\text { Clinical } \\
\text { Impact of CTC }\end{array}$ \\
\hline Meyer 2016 [49] & $\begin{array}{c}152(95 \mathrm{~T} 2,40 \mathrm{~T} 3 \mathrm{a} \\
17 \mathrm{~T} 3 \mathrm{~b})\end{array}$ & CellSearch & $\geq 1 \mathrm{CTC} / 7.5 \mathrm{~mL}$ & $17(11 \%)$ & $0.13(0.13-13.3)$ & $\begin{array}{l}\text { Blood samples collected preoperatively. } \\
\text { Median follow-up } 48 \text { months. }\end{array}$ & No \\
\hline $\begin{array}{l}\text { Toden-höfer } 2016 \\
\text { [50] }\end{array}$ & $50(37 \mathrm{~T} 2,13 \mathrm{~T} 3)$ & $\begin{array}{l}\text { Microfluidic (size, } \\
\text { deforma-bility) }\end{array}$ & $\geq 1 \mathrm{CTC} / 2 \mathrm{~mL}$ & $25(50 \%)$ & $4.5(0.5-208.5)$ & $\begin{array}{l}\text { Pancytokeratin positive CTC showed } \\
\text { expression of androgen receptor. }\end{array}$ & No \\
\hline Kuske 2016 [51] & $\begin{array}{c}86(37 \mathrm{~T} 1,45 \mathrm{~T} 2,4 \\
\mathrm{T} 3)\end{array}$ & $\begin{array}{l}\text { CellSearch } \\
\text { EPISPOT } \\
\text { CellCollector }\end{array}$ & $\geq 1 \mathrm{CTC} / 7.5 \mathrm{~mL}$ & $\begin{array}{c}37 \% \text { CS } \\
54.9 \% \text { CC } \\
58.7 \% \text { EPI }\end{array}$ & $\begin{array}{c}0.24(0.13-1.3) \text { CS } \\
0.32(0.13-1.6) \text { CC } \\
0.4(0.13-1.7) \text { EPI }\end{array}$ & $\begin{array}{c}\text { Blood drawn preoperatively. CTC detected by } \\
\text { EPISPOT correlated to tumor stage, no } \\
\text { correlation found with CellSearch (CS) or } \\
\text { CellCollector (CC) }\end{array}$ & Yes \\
\hline Tsumura 2017 [52] & $\begin{array}{l}59(26 \mathrm{~T} 1 \mathrm{c}-\mathrm{T} 2 \mathrm{a}, 15 \\
\mathrm{T} 2 \mathrm{~b}-\mathrm{c}, 17 \mathrm{~T} 3,1 \mathrm{~T} 4)\end{array}$ & CellSearch & $\geq 1 \mathrm{CTC} / 7.5 \mathrm{~mL}$ & $\begin{array}{c}0(0 \%) \\
\text { preoperative } \\
7(11.8 \%) \\
\text { intraoperative }\end{array}$ & ND & $\begin{array}{l}\text { Blood drawn both before and during surgery, } \\
\text { with detection of CTC only during surgery. }\end{array}$ & No \\
\hline Garcia 2017 [53] & $\begin{array}{c}16 \\
(\mathrm{ND})\end{array}$ & $\begin{array}{l}\text { AR-V7 protein in } \\
\text { serum samples }\end{array}$ & $\begin{array}{l}\text { AR-V7 protein } \\
\text { detection }\end{array}$ & $3(18.7 \%)$ & NA & $\begin{array}{l}\mathrm{CD} 133 \text { expression in CTC was higher among } \\
\text { AR-V7 positive cases vs. AR-V7 negative }\end{array}$ & ND \\
\hline $\begin{array}{c}\text { Puche-Sanz } 2017 \\
{[54]}\end{array}$ & $\begin{array}{c}86 \\
(\mathrm{~T} 1-\mathrm{T} 2)\end{array}$ & $\begin{array}{c}\text { CK } \\
\text { immune-magnetic } \\
\text { Filtration }+\end{array}$ & $\geq 1 \mathrm{CTC} / 10 \mathrm{~mL}$ & $16(18.6 \%)$ & $0(0-0.4)$ & $\begin{array}{l}\text { Blood samples collected before biopsy. } \\
\text { Analysis of AR expression in tumor tissue. }\end{array}$ & Yes \\
\hline Awe 2017 [55] & $41(\mathrm{~T} 1-\mathrm{T} 4)$ & $\begin{array}{l}\text { immunostaining } \\
\text { CK, CD45, AR }\end{array}$ & $\geq 1 \mathrm{CTC} / 3 \mathrm{~mL}$ & $41(100 \%)$ & ND & Blood samples collected before prostatectomy & ND \\
\hline Renier 2017 [56] & $1(\mathrm{ND})$ & $\begin{array}{l}\text { Microfluidic } \\
\text { vortex chip } \\
\text { (size-based) + } \\
\text { immuno-staining } \\
\text { CK, CD45, PSA }\end{array}$ & $\begin{array}{l}>3.37 \mathrm{CTC} / 7.5 \mathrm{~mL} \\
=>0.45 \mathrm{CTC} / \mathrm{mL}\end{array}$ & $1(100 \%)$ & 1.5 & $\begin{array}{l}\text { Some double positive cells (CK+, CD45+) } \\
\text { found but counted as WBC. Some cells did not } \\
\text { express epithelial markers (CK, PSA) but } \\
\text { mesenchymal instead (Vim, N-cad) }\end{array}$ & ND \\
\hline Russo 2018 [57] & 47 (31 T2, 16 T3a) & $\begin{array}{c}\text { AdnaTest } \\
\text { Prostate-Cancer }\end{array}$ & $\begin{array}{l}0.15 \mathrm{ng} / \mu \mathrm{L} \text { for AR, } \\
\text { c-kit, c-met, } \\
\text { ALDH1, TYMS. } \\
0.25 \mathrm{ng} / \mu \mathrm{L} \text { for } \\
\text { Akt-2 \& PI3K } \alpha\end{array}$ & $12(25.5 \%)$ & NA & $\begin{array}{l}\text { Blood samples drawn before prostatectomy. } \\
\text { No healthy controls tested. }\end{array}$ & Yes \\
\hline$\underset{[58]}{\operatorname{Miyamoto}} 2018$ & $\begin{array}{c}34 \\
(22 \mathrm{~T} 1,11 \mathrm{~T} 2,1 \mathrm{~T} 3)\end{array}$ & $\begin{array}{l}\text { CTC-iChip + WTA } \\
\text { + multiplex (8 } \\
\text { genes) ddPCR }\end{array}$ & $\begin{array}{l}\text { Mean CTC in } \\
\text { healthy }+2 S D \text { of } \\
\text { CTC score in } \\
\text { healthy }\end{array}$ & ND & NA & $\begin{array}{l}\text { Blood samples collected before surgery; } 34 \\
\text { age-matched healthy donors included. }\end{array}$ & Yes \\
\hline Murray 2018 [59] & $\begin{array}{c}241 \text { (181 low risk + } \\
60 \text { intermed-iate } \\
\text { risk) }\end{array}$ & $\begin{array}{l}\text { Density gradient }+ \\
\text { PSA ICC }\end{array}$ & $\geq 1 \mathrm{CTC} / 8 \mathrm{~mL}$ & $\begin{array}{c}37 \text { low risk }(20.4 \%) \\
26 \text { intermedi-ate } \\
\text { risk }(43.3 \%)\end{array}$ & ND & $\begin{array}{l}\text { Blood samples collected } 3 \text { months after } \\
\text { radiotherapy and stored } 48 \mathrm{~h} \text { at } 4^{\circ} \mathrm{C} \text {. }\end{array}$ & Yes \\
\hline
\end{tabular}

${ }^{1} \mathrm{ND}=$ Not described. ${ }^{2} \mathrm{NA}=$ Not applicable. $\mathrm{pT}$ stage $=$ Pathological tumor stage. $\mathrm{CTC}=$ Circulating tumor cells. PSA = Prostate-specific antigen. PSMA = Prostate-specific membrane antigen. PSCA $=$ Prostate stem cell antigen. AAM = African Americans. CAM = Caucasian Americans. RT-PCR = Reverse transcription-polymerase chain reaction. EpCAM $=$ Epithelial cell adhesion molecule. AOX = Antioxydant genes. FACS = Fluorescence-activated cell sorting. AR = Androgen receptor. AR-V7 = Androgen receptor splice variant seven. $\mathrm{CK}=$ Cytokeratins. Vim $=$ Vimentin. $\mathrm{N}-\mathrm{Cad}=\mathrm{N}$-Cadherin. WTA $=$ Whole transcriptome amplification. ddPCR $=$ droplet digital polymerase chain reaction. $\mathrm{ICC}=\mathrm{Imunocytochemistry} .2 \mathrm{SD}=$ Two times the standard deviation. 


\section{CTC Detection in Non-Metastatic Prostate Cancer}

In light of the published data, the extensive variability of CTC detection results in the context of localized PCa appears related to the diversity of distinct methods used for CTC collection/detection. Therefore, the present review will classify the published results depending on the CTC collection/detection methods used.

\subsection{CTC Detection by RT-PCR in Non-Metastatic Prostate Cancer}

Reverse transcription-polymerase chain reaction (RT-PCR) is commonly used to generate amplified cDNA from target mRNA [60]. Therefore, the RT-PCR results largely depend on the specific mRNA that is targeted. As a surrogate test for CTC detection in localized PCa, RT-PCR has mainly been used to target the mRNA of prostate-specific antigen (PSA), prostate-specific membrane antigen (PSMA) and prostate stem cell antigen (PSCA). The only study having compared those three targets as surrogate markers of CTC in localized PCa reported that the detection of PSCA mRNA in blood was the most accurate preoperative predictor of disease-free survival (DFS), probably because PSCA was the only mRNA not detected in 71 non-malignant disorders (PSA detected in 1 and PSMA in 2 of 71 non-malignant disorders) [29]. However, the very low detection rate of PSCA mRNA in that study (detected in only 1 of 43 localized PCa patients) begs caution when interpreting the results. Additionally, Joung et al. reported no association of PSCA mRNA detection with clinical variables on a larger cohort of localized PCa patients [39].

Most studies have focused on PSA and PSMA detection in localized PCa and have yielded somewhat contradictory results. Sabile et al. reported that the density gradient separation of mononuclear cells had a higher isolation efficiency than epithelial marker-dependent immunocapture for CTC detection based on PSA RT-PCR [23]. However, by using density gradient separation and PSA RT-PCR, Moreno et al. failed to detect CTC in 4 patients with localized PCa, possibly owing to distinct RT-PCR primer sequences [17]. By studying patients with a mean follow-up of 13.6 months, Olsson et al. determined that PSA mRNA detection was a significant predictor of disease recurrence after prostatectomy [19] while Mejean et al. found a statistical association of PSA-positive RT-PCR with metastasis and recurrence after a follow-up of 26 months [24]. Interestingly, the latter study also tested 11 patients with prostatitis and found positive PSA RT-PCR results in 2 of 11 cases (18\%). Other studies including longer follow-up periods reported no correlation of PSA mRNA detection with clinical variables such as overall survival (OS), progression-free survival (PFS), Gleason score, tumor stage or preoperative serum PSA level $[20,21,25,27,30,31,34]$. Israeli et al. reported that PSMA RT-PCR was more sensitive than PSA RT-PCR in detecting hematogenous tumor cell dissemination but their results were not correlated to clinical variables [18]. Okegawa et al. compared the detection of PSA and PSMA mRNAs as prognostic indicators in a small cohort of 31 localized PCa and determined that PSMA mRNA detection in blood was a significant predictor of PFS after a mean of 16.7 months of follow-up [22]. In contrast, studies including larger casistics and longer follow-up times reported no significant correlation of PSMA mRNA detection with clinical variables [30,34]. Eschwege et al. argued that more specific PSMA RT-PCR primers should be used and that only dual PSA-PSMA-positive blood samples could be considered as reflecting the presence of CTC in blood [36]. Interestingly, the latter study included a rather large cohort of 155 localized PCa patients, more than 100 healthy controls, none of which tested positive for both PSA and PSMA, and 5-year follow-up data showing that the preoperative detection of both PSA and PSMA mRNAs in blood was an independent prognostic factor of disease recurrence [36]. Similarly, Yates et al. showed that both PSA and PSMA mRNA detection improved the prediction of biochemical recurrence over Kattan nomogram [40]. Slawin et al. took a slightly different approach by amplifying the human KLK2 gene, coding for an androgen-regulated protein (hK2) that has an $80 \%$ amino acid sequence identity with PSA [26]. Although the Authors determined that RT-PCR-hK2 results allowed for the prediction of lymph node-positive disease, the positivity of their test in $14 \%$ of 14 healthy controls indicates a lack of specificity of CTC detection via hK2 RT-PCR [26]. Multiplex RT-PCR approaches may be more efficient in identifying hematogenous 
prostatic cell dissemination. Yet, the major shortcoming of any RT-PCR approach as a surrogate marker for CTC detection is the related inability to count and further characterize CTC from blood. Furthermore, methodological variability related to different cell extraction methods, primers used for RT-PCR, controls of specificity and sensitivity and the timing of sample collection and storage is expected to account for the heterogeneity of the results obtained and their clinical relevance.

\subsection{CTC Detection by CellSearch in Non-Metastatic Prostate Cancer}

The CellSearch method uses the epithelial cell adhesion molecule (EpCAM) to capture circulating cells and defines CTC as nucleated cells (DAPI+) of epithelial (CK+) and non-hematopoietic (CD45-) origin, which, in fact, better corresponds to a definition of circulating epithelial cells (CEpC). It is important to note that $\mathrm{CEpC}$ have been found in the blood of patients with benign colon diseases [61] and benign pancreatic diseases [62]. The lack of specificity of the CellSearch method is exemplified by the finding of СTC in up to $20 \%$ of healthy donors tested [33].

The preoperative detection of CTC by CellSearch in localized PCa has been reported in $0 \%$ to $73 \%$ of patients, depending on the study (see Table 1). The fact that distinct cutoff values were used to define CTC positivity in those studies complicates the task to compare their results. For example, Davis et al. and Pal et al. chose to place the cutoff at 1 CTC per $22.5 \mathrm{~mL}$ of blood, corresponding to the finding of at least 1 CTC in 3 CellSearch samples of $7.5 \mathrm{~mL}$ each $[33,47]$. In contrast, the majority of studies using CellSearch to detect CTC in localized PCa have used a cutoff of 1 CTC in 7.5 mL [41-44,49,51]. None of the ten studies using CellSearch to detect CTC in localized PCa have reported a significant correlation of CTC numbers with clinical variables such as OS, PFS, Gleason score, tumor stage or preoperative serum PSA level.

\subsection{CTC Detection by Other Marker-Dependent Methods in Non-Metastatic Prostate Cancer}

A recent study comparing CellSearch with another EpCAM-dependent method (CellCollector) and the EPISPOT assay (based on the negative enrichment of CTC by leukocyte depletion) reported that only CTC detected by EPISPOT in $58.7 \%$ of patients were significantly correlated with clinical parameters such as PSA serum values $(p<0.0001)$ and the clinical tumor stage $(p=0.04)$ [51]. Using the EpCAM-dependent immune-magnetic enrichment of CTC followed by telomerase detection via an enzyme-linked immunosorbent assay, Fizazi et al. detected CTC in 70\% of 83 localized PCa patients without false-positive results in 22 healthy controls tested [32]. Unfortunately, the latter study did not include any prognostic evaluation. The EPCAM-dependent microfluidic isolation of CTC has been reported by Stott et al., showing the detection of up to 222 CTC per $\mathrm{mL}$ of blood tested and a decline of CTC numbers in 6 of 8 patients $24 \mathrm{~h}$ after radical prostatectomy [38]. However, in the latter study, the finding of CTC in healthy controls implied the need for a cutoff value at 14 CTC per mL of blood. By using the AdnaTest, relying on EpCAM and MUC-1 antigens for immune-magnetic isolation and on RT-PCR of Androgen Receptor (AR), c-kit, c-met, ALDH1 and TYMPS for CTC detection, Russo et al. failed to demonstrate a significant association of CTC with clinical parameters [57]. In contrast, Puche-Sanz et al. used cytokeratin-mediated immune-magnetic enrichment of CTC and reported a significant correlation of CTC detection with AR expression in the tumor tissue [54]. The assessment of the AR-V7 splice variant protein in plasma, performed through a capillary nano-immunoassay platform was proposed by Garcia et al. as a surrogate marker for CTC in localized PCa patients [53]. Interestingly, the authors reported a significant correlation of AR-V7 detection with preoperative serum PSA levels and the expression of the stem cell marker CD133. However, the latter study did not perform a longitudinal follow-up of localized PCa patients for further prognostic evaluation [53]. Murray et al. took a different approach by using density gradient isolation and detection of CTC by PSA immunocytochemistry on a large cohort of localized PCa patients [59]. Importantly, the authors reported a significant correlation between CTC detection and clinical variables such as PFS after a long follow-up period of 15 years. However, Murray et al. stored the blood samples at $4{ }^{\circ} \mathrm{C}$ during $48 \mathrm{~h}$ 
before analyzing them, which could significantly impact the CTC detection results. Furthermore, the authors neither provided counting of the CTC nor exemplar CTC images.

\subsection{CTC Detection Following Size-Based Isolation Methods in Non-Metastatic Prostate Cancer}

To date, few studies have used size-based separation methods to study CTC from localized PCa patients. Giesing et al. were the first to use blood filtration followed by RT-PCR of PSA and a selection of antioxidant genes (AOX) to detect CTC in 42 localized PCa patients [37]. The authors determined that the detection of antioxidant gene expression in CTC could predict tumor diagnosis with $86 \%$ sensitivity and $82 \%$ specificity. A few years later, Kolostova et al. used MetaCell@filtration followed by a short-term in vitro culture to identify CTC in 28 of 55 localized PCa patients [45]. Unfortunately, no correlation was found between CTC detection and the clinical parameters. Similarly, Todenhöfer et al. failed to demonstrate a significant correlation with the clinical parameters of CTC detected by fluorescence imaging (EpCAM+ \& CD45-) following microfluidic enrichment based on cell-size and deformability [50]. Interestingly, Renier et al. used a similar size-based microfluidic enrichment of CTC followed by the immunofluorescent detection of cytokeratins (CK), PSA and CD45 and reported that some cells did not express epithelial markers (CK) but mesenchymal markers instead (Vim, N-cad), thereby pointing to the process of epithelial to mesenchymal transition (EMT) in circulating prostate cells [56]. Awe et al. also reported on distinct subpopulations of CTC following size-based enrichment and immunostaining for cytokeratins, CD45 and the androgen receptor (AR) but they did not evaluate the clinical impact of those CTC [55]. Efficient risk stratification of localized PCa patients by means of a liquid biopsy was only recently achieved by Miyamoto et al. using the size-based microfluidic enrichment of CTC followed by whole transcriptome amplification and multiplex droplet digital PCR of a panel of 8 genes [58]. By using the differential weighting of 6 genes from the panel, the authors could predict early prostate cancer dissemination in localized disease [58].

\section{Analysis of the Clinical Value of CTC Detection in Localized Prostate Cancer (Stages T1, T2)}

Among the 43 studies targeting non-metastatic patients with PCa included in the present review, 31 investigated the potential clinical impact of CTC detection, looking for a statistical correlation between the detection of CTC and PCa clinical and/or pathological characteristics. Studies reporting on PCa with early (T1-T2) and advanced (T3-T4) stages but without a separate statistical analysis of $\mathrm{T} 1-\mathrm{T} 2$ cancers were further excluded. The details of the remaining 11 studies reporting on the analysis of the clinical value of CTC detection in localized (T1-T2) PCa are shown in Table 2. For clarity, the diagnostic value refers to a test's ability to identify a disease or a specific condition, with degrees of specificity and sensitivity to express its confidence and accuracy [63]. The predictive value refers to a test's ability to predict the patient's response to a specific treatment while its prognostic value identifies risks of progression of the disease independently of a specific treatment [64]. 
Table 2. The clinical value of Circulating Tumor Cells' (CTC) detection in patients with localized prostate cancer.

\begin{tabular}{|c|c|c|c|c|c|c|}
\hline Study [ref] & Method & $\mathbf{N}^{\circ}$ of Patients & $\begin{array}{c}\mathrm{N}^{\circ} \text { of CTC+ Patients } \\
(\%)\end{array}$ & $\begin{array}{l}\text { Mean Follow-Up } \\
\text { Period }\end{array}$ & $\begin{array}{c}\text { Type of Clinical Value } \\
\text { ( } P \text { Value })\end{array}$ & Comments \\
\hline Olsson 1996 [19] & PSA RT-PCR & 100 (cT1-cT2c) & $74(74 \%)$ & 13.6 months & $\begin{array}{l}\text { Predictive of surgical } \\
\text { failure }(P<0.0286)\end{array}$ & $\begin{array}{l}\text { Correlation of RT-PCR results before } \\
\text { prostatectomy with disease recurrence } \\
\text { after prostatectomy. }\end{array}$ \\
\hline Ennis 1997 [20] & PSA RT-PCR & 156 (cT1-cT2) & ND & ND & Prognostic $(P<0.0001)$ & $\begin{array}{l}\text { Correlation of RT-PCR results with } \\
\text { pathological stage and prediction of } \\
\text { extra-capsular disease. }\end{array}$ \\
\hline Mejean 2000 [24] & PSA RT-PCR & 79 (cT1-cT2) & ND & 26 months & Predictive $(P<0.04)$ & $\begin{array}{l}\text { CTC detection associated with the } \\
\text { development of metastases and risk of } \\
\text { relapse after prostatectomy. }\end{array}$ \\
\hline Slawin 2000 & hK2 RT-PCR & 154 (pT1-pT2) & ND & ND & Prognostic $(P=0.028)$ & $\begin{array}{l}\text { Association with the risk of metastasis to } \\
\text { pelvic lymph nodes. }\end{array}$ \\
\hline Bianco 2002 [28] & PSA RT-PCR & 96 (35 pT1, 61 рT2) & $\begin{array}{l}26(27 \%) \text { African } \\
\text { Americans }\end{array}$ & 33 months & Prognostic $(P=0.01)$ & $\begin{array}{l}\text { Association with tumor stage and } \\
\text { recurrence in African-Americans. }\end{array}$ \\
\hline Yates 2012 [40] & PSA \& PSMA RT-PCR & 92 (61 pT1, 31 рT2) & $\begin{array}{c}63(68.5 \%) \text { PSA } \\
68(78.9 \%) \text { PSMA }\end{array}$ & 72 months & Predictive $(P=0.03)$ & $\begin{array}{l}\text { Improved prediction of biochemical } \\
\text { recurrence. }\end{array}$ \\
\hline Puche-Sanz 2017 [54] & CK immune-magnetic & $86(\mathrm{pT} 1-\mathrm{pT} 2)$ & $16(18.6 \%)$ & ND & $\begin{array}{l}\text { Theranostic \& Diagnostic } \\
\quad(P=0.03)\end{array}$ & $\begin{array}{c}\text { Expression of AR in tumor tissue } \\
\text { correlated significantly with presence of } \\
\text { CTC in blood. Diagnosis of PCa by CTC } \\
\text { has a } 14.2 \% \text { sensitivity and a } 78.4 \% \\
\text { specificity. }\end{array}$ \\
\hline Llanes 2000 [25] & PSA RT-PCR & 25 (pT1-pT2b) & $7(28 \%)$ & ND & Not significant & $\begin{array}{c}\text { The best predictors of extraprostatic } \\
\text { disease were the biopsy Gleason score } \\
\text { and the PSA level. }\end{array}$ \\
\hline Shariat $2002[27]$ & $\begin{array}{l}\text { PSA RT-PCR } \\
\text { HK2L }\end{array}$ & 224 (рT1-pT2) & $54(24 \%)$ & 52.9 months & Not significant & $\begin{array}{c}\text { Preoperative blood RT-PCR-PSA not } \\
\text { associated with characteristics or } \\
\text { outcomes of prostate cancer } \\
\text { HK2L correlation with risk of } \\
\text { metastases. }\end{array}$ \\
\hline Thomas 2002 [30] & PSA \& PSMA RT-PCR & 136 (pT1-pT2) & $73(54 \%)$ & 59 months & Not significant & $\begin{array}{l}\text { RT-PCR status did not predict } \\
\text { pathologic stage or biochemical failure. } \\
\text { No association between KLK mRNA }\end{array}$ \\
\hline Helo 2009 [34] & PSA \& PSMA RT-PCR & $87(\mathrm{cT} 1-\mathrm{cT} 2)$ & $6(7 \%)$ & 28 months & Not significant & $\begin{array}{c}\text { status and unfavorable localized disease } \\
\text { features. }\end{array}$ \\
\hline
\end{tabular}


The first conclusion of our literature review is that very few studies investigated the clinical impact of CTC selectively in patients with localized prostate cancer. Overall, there is a definite trend toward a value of CTC in correlation with the pathological stage and toward a prognostic and predictive impact of CTC detection in early-stage prostate cancer since several studies have reported significant correlations of CTC numbers with the survival of patients and/or recurrence of the disease after treatment $[19,20,24,28,40]$. However, those studies used PSA RT-PCR to detect CTC, a method which has yielded contradictory results in other studies [25,27,34], thereby calling for further validation of those results in large cohorts of localized PCa patients. The diagnostic value of CTC detection in early-stage prostate cancer has been less extensively investigated than in metastatic patients. In this regard, the most interesting results come from Giesing et al. with a CTC test demonstrating an $86 \%$ sensitivity and an $82 \%$ specificity with a $69 \%$ positive predictive value and a $92 \%$ negative predictive value for PCa diagnosis [37]. However, the latter study reported on both early-stage (T1-T2) and locally advanced (T3-T4) PCa. Puche-Sanz et al. have also investigated the possibility of a diagnostic CTC test for PCa [54]. Yet, with a $14.2 \%$ sensitivity and a $78.4 \%$ specificity, their test would not further improve on the PSA screening test. The lack of further investigation of a potential diagnostic CTC test could, in fact, stem from the substantial difficulty of detecting CTC in a consistent and specific manner in the context of localized PCa. The presence of circulating prostatic cells in benign prostatic hyperplasia and prostatitis impacts the specificity of certain CTC isolation techniques such as PSA RT-PCR [24,29]. Furthermore, the phenotypic heterogeneity of CTC has been established in the context of metastatic $\mathrm{PCa}$ [65]. Additionally, the occurrence of a phenotypic transition (EMT) in CTC from early-stage PCa patients, evidenced by Renier et al. [56], supports the notion of phenotypic heterogeneity among CTC from localized PCa patients as well. The heterogeneity of CTC is relevant to the potential theranostic interest of various CTC tests. Particularly, the expression of the androgen receptor (AR) is of substantial importance for therapy strategy decision in PCa. In fact, a recent review evaluating clinical trials in the context of metastatic PCa determined that the expression of a specific variant of the androgen receptor (AR-V7) was significantly correlated to the limited efficacy of abiraterone and enzalutamide treatments compared with taxane therapy [66]. Whether such an association still holds true in the context of early-stage PCa remains to be demonstrated. Miyamoto et al. also reported a considerable heterogeneity among prostate CTC, including heterogeneous patterns of AR splice variant expression, following microfluidic enrichment and single-cell RNA-seq analyses [67]. So far, only two studies have reported correlations of CTC detection in localized PCa patients with AR expression [54,57]. Puche-Sanz et al. observed a direct association of the expression of AR in the prostatic tissue and the presence of CTC in blood [54]. Russo et al. determined that the expression of AR and TYMS on CTC are frequent events but the implications of such results for a personalized treatment strategy in PCa remain to be elucidated [57]. Further studies are needed to evaluate the potential theranostic utility of CTC in the context of localized PCa.

\section{Perspectives and Future Directions}

The major issue concerning localized prostate cancer is the lack of a suitable marker which could identify benign cases from aggressive prostate cancers. The present study shows a trend toward a possible clinical impact of CTC detection in patients with localized prostate cancer. Despite this trend, the study raises key issues in particular about the technical approaches used, the need for CTC counting and characterization, the sensitivity and specificity controls and the timing of blood sampling. Overall, our analysis encourages the development of a CTC cell-based specific test able to identify and count CTC in a highly sensitive and specific manner in patients with localized cancers and single-cell CTC analyses in patients with localized prostate cancer to specifically study the CTC heterogeneity. It also stimulates the use of a standardized approach to be employed in large clinical studies.

Funding: This work was supported by funds from: Fondation pour la Recherche Médicale, Fondation Bettencourt-Schueller, Fondation Lefort-Beaumont de l'Institut de France, INSERM and Université Paris-Descartes. 
Conflicts of Interest: Professor Patrizia Paterlini-Brechot is co-inventor of ISET®patents belonging to University Paris Descartes, INSERM and Assistance Publique Hopitaux de Paris, exclusively licensed to Rarecells Diagnostics, France. This author does not receive payments from Rarecells Diagnostics. The present study was conducted independently by academic research teams.

\section{References}

1. Pernar, C.H.; Ebot, E.M.; Wilson, K.M.; Mucci, L.A. The Epidemiology of Prostate Cancer. Cold Spring Harb. Perspect. Med. 2018, 8. [CrossRef] [PubMed]

2. Siegel, R.L.; Miller, K.D.; Jemal, A. Cancer statistics, 2018. CA Cancer J. Clin. 2018, 68, 7-30. [CrossRef] [PubMed]

3. Daniyal, M.; Siddiqui, Z.A.; Akram, M.; Asif, H.M.; Sultana, S.; Khan, A. Epidemiology, etiology, diagnosis and treatment of prostate cancer. Asian Pac. J. Cancer Prev. 2014, 15, 9575-9578. [CrossRef] [PubMed]

4. Cancer of the Prostate-Cancer Stat Facts. Available online: https://seer.cancer.gov/statfacts/html/prost.html (accessed on 31 May 2019).

5. Jahn, J.L.; Giovannucci, E.L.; Stampfer, M.J. The high prevalence of undiagnosed prostate cancer at autopsy: implications for epidemiology and treatment of prostate cancer in the Prostate-specific Antigen-era. Int. J. Cancer 2015, 137, 2795-2802. [CrossRef] [PubMed]

6. Baca, S.C.; Prandi, D.; Lawrence, M.S.; Mosquera, J.M.; Romanel, A.; Drier, Y.; Park, K.; Kitabayashi, N.; MacDonald, T.Y.; Ghandi, M.; et al. Punctuated evolution of prostate cancer genomes. Cell 2013, 153, 666-677. [CrossRef] [PubMed]

7. Heidenreich, A.; Bastian, P.J.; Bellmunt, J.; Bolla, M.; Joniau, S.; van der Kwast, T.; Mason, M.; Matveev, V.; Wiegel, T.; Zattoni, F.; et al. EAU guidelines on prostate cancer. part 1: Screening, diagnosis, and local treatment with curative intent-update 2013. Eur. Urol. 2014, 65, 124-137. [CrossRef] [PubMed]

8. Holmberg, L.; Bill-Axelson, A.; Helgesen, F.; Salo, J.O.; Folmerz, P.; Häggman, M.; Andersson, S.-O.; Spångberg, A.; Busch, C.; Nordling, S.; et al. A randomized trial comparing radical prostatectomy with watchful waiting in early prostate cancer. N. Engl. J. Med. 2002, 347, 781-789. [CrossRef] [PubMed]

9. Barry, M.J.; Simmons, L.H. Prevention of Prostate Cancer Morbidity and Mortality: Primary Prevention and Early Detection. Med. Clin. N. Am. 2017, 101, 787-806. [CrossRef]

10. Akizhanova, M.; Iskakova, E.E.; Kim, V.; Wang, X.; Kogay, R.; Turebayeva, A.; Sun, Q.; Zheng, T.; Wu, S.; Miao, L.; et al. PSA and Prostate Health Index based prostate cancer screening in a hereditary migration complicated population: Implications in precision diagnosis. J. Cancer 2017, 8, 1223-1228. [CrossRef]

11. Galper, S.L.; Chen, M.-H.; Catalona, W.J.; Roehl, K.A.; Richie, J.P.; D'Amico, A.V. Evidence to support a continued stage migration and decrease in prostate cancer specific mortality. J. Urol. 2006, 175, 907-912. [CrossRef]

12. Tsodikov, A.; Gulati, R.; Heijnsdijk, E.A.M.; Pinsky, P.F.; Moss, S.M.; Qiu, S.; de Carvalho, T.M.; Hugosson, J.; Berg, C.D.; Auvinen, A.; et al. Reconciling the Effects of Screening on Prostate Cancer Mortality in the ERSPC and PLCO Trials. Ann. Intern. Med. 2017, 167, 449-455. [CrossRef] [PubMed]

13. Pound, C.R.; Partin, A.W.; Eisenberger, M.A.; Chan, D.W.; Pearson, J.D.; Walsh, P.C. Natural history of progression after PSA elevation following radical prostatectomy. JAMA 1999, 281, 1591-1597. [CrossRef] [PubMed]

14. Doyen, J.; Alix-Panabières, C.; Hofman, P.; Parks, S.K.; Chamorey, E.; Naman, H.; Hannoun-Lévi, J.-M. Circulating tumor cells in prostate cancer: A potential surrogate marker of survival. Crit. Rev. Oncol. Hematol. 2012, 81, 241-256. [CrossRef] [PubMed]

15. Hegemann, M.; Stenzl, A.; Bedke, J.; Chi, K.N.; Black, P.C.; Todenhöfer, T. Liquid biopsy: Ready to guide therapy in advanced prostate cancer? BJU Int. 2016, 118, 855-863. [CrossRef] [PubMed]

16. Borley, N.; Feneley, M.R. Prostate cancer: Diagnosis and staging. Asian J. Androl. 2009, 11, 74-80. [CrossRef] [PubMed]

17. Moreno, J.G.; Croce, C.M.; Fischer, R.; Monne, M.; Vihko, P.; Mulholland, S.G.; Gomella, L.G. Detection of hematogenous micrometastasis in patients with prostate cancer. Cancer Res. 1992, 52, 6110-6112.

18. Israeli, R.S.; Miller, W.H.; Su, S.L.; Samadi, D.S.; Powell, C.T.; Heston, W.D.; Wise, G.J.; Fair, W.R. Sensitive detection of prostatic hematogenous tumor cell dissemination using prostate specific antigen and prostate specific membrane-derived primers in the polymerase chain reaction. J. Urol. 1995, 153, 573-577. 
19. Olsson, C.A.; de Vries, G.M.; Raffo, A.J.; Benson, M.C.; O’Toole, K.; Cao, Y.; Buttyan, R.E.; Katz, A.E. Preoperative reverse transcriptase polymerase chain reaction for prostate specific antigen predicts treatment failure following radical prostatectomy. J. Urol. 1996, 155, 1557-1562. [CrossRef]

20. Ennis, R.D.; Katz, A.E.; de Vries, G.M.; Heitjan, D.F.; O’Toole, K.M.; Rubin, M.; Buttyan, R.; Benson, M.C.; Schiff, P.B. Detection of circulating prostate carcinoma cells via an enhanced reverse transcriptase-polymerase chain reaction assay in patients with early stage prostate carcinoma. Independence from other pretreatment characteristics. Cancer 1997, 79, 2402-2408. [CrossRef]

21. Oefelein, M.G.; Ignatoff, J.M.; Clemens, J.Q.; Watkin, W.; Kaul, K.L. Clinical and molecular followup after radical retropubic prostatectomy. J. Urol. 1999, 162, 307-310. [CrossRef]

22. Okegawa, T.; Nutahara, K.; Higashihara, E. Preoperative nested reverse transcription-polymerase chain reaction for prostate specific membrane antigen predicts biochemical recurrence after radical prostatectomy. BJU Int. 1999, 84, 112-117. [CrossRef] [PubMed]

23. Sabile, A.; Louha, M.; Bonte, E.; Poussin, K.; Vona, G.; Mejean, A.; Chretien, Y.; Bougas, L.; Lacour, B.; Capron, F; et al. Efficiency of Ber-EP4 antibody for isolating circulating epithelial tumor cells before RT-PCR detection. Am. J. Clin. Pathol. 1999, 112, 171-178. [CrossRef] [PubMed]

24. Mejean, A.; Vona, G.; Nalpas, B.; Damotte, D.; Brousse, N.; Chretien, Y.; Dufour, B.; Lacour, B.; Bréchot, C.; Paterlini-Bréchot, P. Detection of circulating prostate derived cells in patients with prostate adenocarcinoma is an independent risk factor for tumor recurrence. J. Urol. 2000, 163, 2022-2029. [CrossRef]

25. Llanes, L.; Páez, A.; Ferruelo, A.; Luján, M.; Romero, I.; Berenguer, A. Detecting circulating prostate cells in patients with clinically localized prostate cancer: Clinical implications for molecular staging. BJU Int. 2000, 86, 1023-1027. [CrossRef] [PubMed]

26. Slawin, K.M.; Shariat, S.F.; Nguyen, C.; Leventis, A.K.; Song, W.; Kattan, M.W.; Young, C.Y.; Tindall, D.J.; Wheeler, T.M. Detection of metastatic prostate cancer using a splice variant-specific reverse transcriptase-polymerase chain reaction assay for human glandular kallikrein. Cancer Res. 2000, 60, 7142-7148. [PubMed]

27. Shariat, S.F.; Gottenger, E.; Nguyen, C.; Song, W.; Kattan, M.W.; Andenoro, J.; Wheeler, T.M.; Spencer, D.M.; Slawin, K.M. Preoperative blood reverse transcriptase-PCR assays for prostate-specific antigen and human glandular kallikrein for prediction of prostate cancer progression after radical prostatectomy. Cancer Res. 2002, 62, 5974-5979. [PubMed]

28. Bianco, F.J.; Powell, I.J.; Cher, M.L.; Wood, D.P. Presence of circulating prostate cancer cells in African American males adversely affects survival. Urol. Oncol. 2002, 7, 147-152. [CrossRef]

29. Hara, N.; Kasahara, T.; Kawasaki, T.; Bilim, V.; Obara, K.; Takahashi, K.; Tomita, Y. Reverse transcription-polymerase chain reaction detection of prostate-specific antigen, prostate-specific membrane antigen, and prostate stem cell antigen in one milliliter of peripheral blood: Value for the staging of prostate cancer. Clin. Cancer Res. 2002, 8, 1794-1799.

30. Thomas, J.; Gupta, M.; Grasso, Y.; Reddy, C.A.; Heston, W.D.; Zippe, C.; Dreicer, R.; Kupelian, P.A.; Brainard, J.; Levin, H.S.; et al. Preoperative combined nested reverse transcriptase polymerase chain reaction for prostate-specific antigen and prostate-specific membrane antigen does not correlate with pathologic stage or biochemical failure in patients with localized prostate cancer undergoing radical prostatectomy. J. Clin. Oncol. 2002, 20, 3213-3218.

31. Gewanter, R.M.; Katz, A.E.; Olsson, C.A.; Benson, M.C.; Singh, A.; Schiff, P.B.; Ennis, R.D. RT-PCR for PSA as a prognostic factor for patients with clinically localized prostate cancer treated with radiotherapy. Urology 2003, 61, 967-971. [CrossRef]

32. Fizazi, K.; Morat, L.; Chauveinc, L.; Prapotnich, D.; De Crevoisier, R.; Escudier, B.; Cathelineau, X.; Rozet, F.; Vallancien, G.; Sabatier, L.; et al. High detection rate of circulating tumor cells in blood of patients with prostate cancer using telomerase activity. Ann. Oncol. 2007, 18, 518-521. [CrossRef] [PubMed]

33. Davis, J.W.; Nakanishi, H.; Kumar, V.S.; Bhadkamkar, V.A.; McCormack, R.; Fritsche, H.A.; Handy, B.; Gornet, T.; Babaian, R.J. Circulating tumor cells in peripheral blood samples from patients with increased serum prostate specific antigen: Initial results in early prostate cancer. J. Urol. 2008, 179, 2187-2191. [CrossRef] [PubMed] 
34. Helo, P.; Cronin, A.M.; Danila, D.C.; Wenske, S.; Gonzalez-Espinoza, R.; Anand, A.; Koscuiszka, M.; Väänänen, R.-M.; Pettersson, K.; Chun, F.K.-H.; et al. Circulating prostate tumor cells detected by reverse transcription-PCR in men with localized or castration-refractory prostate cancer: Concordance with CellSearch assay and association with bone metastases and with survival. Clin. Chem. 2009, 55, 765-773. [CrossRef] [PubMed]

35. Maestro, L.M.; Sastre, J.; Rafael, S.B.; Veganzones, S.B.; Vidaurreta, M.; Martín, M.; Olivier, C.; de La Orden, V.B.; Garcia-Saenz, J.A.; Alfonso, R.; et al. Circulating tumor cells in solid tumor in metastatic and localized stages. Anticancer Res. 2009, 29, 4839-4843. [PubMed]

36. Eschwège, P.; Moutereau, S.; Droupy, S.; Douard, R.; Gala, J.-L.; Benoit, G.; Conti, M.; Manivet, P.; Loric, S. Prognostic value of prostate circulating cells detection in prostate cancer patients: A prospective study. Br. J. Cancer 2009, 100, 608-610. [CrossRef] [PubMed]

37. Giesing, M.; Suchy, B.; Driesel, G.; Molitor, D. Clinical utility of antioxidant gene expression levels in circulating cancer cell clusters for the detection of prostate cancer in patients with prostate-specific antigen levels of 4-10 ng/mL and disease prognostication after radical prostatectomy. BJU Int. 2010, 105, 1000-1010. [CrossRef] [PubMed]

38. Stott, S.L.; Lee, R.J.; Nagrath, S.; Yu, M.; Miyamoto, D.T.; Ulkus, L.; Inserra, E.J.; Ulman, M.; Springer, S.; Nakamura, Z.; et al. Isolation and characterization of circulating tumor cells from patients with localized and metastatic prostate cancer. Sci. Transl. Med. 2010, 2, 25ra23. [CrossRef] [PubMed]

39. Joung, J.Y.; Cho, K.S.; Kim, J.E.; Seo, H.K.; Chung, J.; Park, W.S.; Choi, M.K.; Lee, K.H. Prostate stem cell antigen mRNA in peripheral blood as a potential predictor of biochemical recurrence in high-risk prostate cancer. J. Surg. Oncol. 2010, 101, 145-148. [CrossRef]

40. Yates, D.R.; Rouprêt, M.; Drouin, S.J.; Comperat, E.; Ricci, S.; Lacave, R.; Sèbe, P.; Cancel-Tassin, G.; Bitker, M.-O.; Cussenot, O. Quantitative RT-PCR analysis of PSA and prostate-specific membrane antigen mRNA to detect circulating tumor cells improves recurrence-free survival nomogram prediction after radical prostatectomy. Prostate 2012, 72, 1382-1388. [CrossRef]

41. Lowes, L.E.; Lock, M.; Rodrigues, G.; D’Souza, D.; Bauman, G.; Ahmad, B.; Venkatesan, V.; Allan, A.L.; Sexton, T. Circulating tumour cells in prostate cancer patients receiving salvage radiotherapy. Clin. Transl. Oncol. 2012, 14, 150-156. [CrossRef]

42. Khurana, K.K.; Grane, R.; Borden, E.C.; Klein, E.A. Prevalence of circulating tumor cells in localized prostate cancer. Curr. Urol. 2013, 7, 65-69. [CrossRef] [PubMed]

43. Thalgott, M.; Rack, B.; Maurer, T.; Souvatzoglou, M.; Eiber, M.; Kreß, V.; Heck, M.M.; Andergassen, U.; Nawroth, R.; Gschwend, J.E.; et al. Detection of circulating tumor cells in different stages of prostate cancer. J. Cancer Res. Clin. Oncol. 2013, 139, 755-763. [CrossRef] [PubMed]

44. Loh, J.; Jovanovic, L.; Lehman, M.; Capp, A.; Pryor, D.; Harris, M.; Nelson, C.; Martin, J. Circulating tumor cell detection in high-risk non-metastatic prostate cancer. J. Cancer Res. Clin. Oncol. 2014, 140, 2157-2162. [CrossRef] [PubMed]

45. Kolostova, K.; Broul, M.; Schraml, J.; Cegan, M.; Matkowski, R.; Fiutowski, M.; Bobek, V. Circulating tumor cells in localized prostate cancer: Isolation, cultivation in vitro and relationship to T-stage and Gleason score. Anticancer Res. 2014, 34, 3641-3646. [PubMed]

46. Shao, C.; Liao, C.-P.; Hu, P.; Chu, C.-Y.; Zhang, L.; Bui, M.H.T.; Ng, C.S.; Josephson, D.Y.; Knudsen, B.; Tighiouart, M.; et al. Detection of live circulating tumor cells by a class of near-infrared heptamethine carbocyanine dyes in patients with localized and metastatic prostate cancer. PLoS ONE 2014, 9, e88967. [CrossRef] [PubMed]

47. Pal, S.K.; He, M.; Wilson, T.; Liu, X.; Zhang, K.; Carmichael, C.; Torres, A.; Hernandez, S.; Lau, C.; Agarwal, N.; et al. Detection and phenotyping of circulating tumor cells in high-risk localized prostate cancer. Clin. Genitourin. Cancer 2015, 13, 130-136. [CrossRef] [PubMed]

48. Thalgott, M.; Rack, B.; Horn, T.; Heck, M.M.; Eiber, M.; Kübler, H.; Retz, M.; Gschwend, J.E.; Andergassen, U.; Nawroth, R. Detection of Circulating Tumor Cells in Locally Advanced High-risk Prostate Cancer During Neoadjuvant Chemotherapy and Radical Prostatectomy. Anticancer Res. 2015, 35, 5679-5685. 
49. Meyer, C.P.; Pantel, K.; Tennstedt, P.; Stroelin, P.; Schlomm, T.; Heinzer, H.; Riethdorf, S.; Steuber, T. Limited prognostic value of preoperative circulating tumor cells for early biochemical recurrence in patients with localized prostate cancer. Urol. Oncol. 2016, 34, 235.e11-235.e16. [CrossRef]

50. Todenhöfer, T.; Park, E.S.; Duffy, S.; Deng, X.; Jin, C.; Abdi, H.; Ma, H.; Black, P.C. Microfluidic enrichment of circulating tumor cells in patients with clinically localized prostate cancer. Urol. Oncol. 2016, 34, 483.e9-483.e16. [CrossRef]

51. Kuske, A.; Gorges, T.M.; Tennstedt, P.; Tiebel, A.-K.; Pompe, R.; Preißer, F.; Prues, S.; Mazel, M.; Markou, A.; Lianidou, E.; et al. Improved detection of circulating tumor cells in non-metastatic high-risk prostate cancer patients. Sci. Rep. 2016, 6, 39736. [CrossRef]

52. Tsumura, H.; Satoh, T.; Ishiyama, H.; Tabata, K.-I.; Takenaka, K.; Sekiguchi, A.; Nakamura, M.; Kitano, M.; Hayakawa, K.; Iwamura, M. Perioperative Search for Circulating Tumor Cells in Patients Undergoing Prostate Brachytherapy for Clinically Nonmetastatic Prostate Cancer. Int. J. Mol. Sci. 2017, 18. [CrossRef] [PubMed]

53. García, J.L.; Lozano, R.; Misiewicz-Krzeminska, I.; Fernández-Mateos, J.; Krzeminski, P.; Alfonso, S.; Marcos, R.A.; García, R.; Gómez-Veiga, F.; Virseda, Á.; et al. A novel capillary nano-immunoassay for assessing androgen receptor splice variant 7 in plasma. Correlation with CD133 antigen expression in circulating tumor cells. A pilot study in prostate cancer patients. Clin. Transl. Oncol. 2017, 19, 1350-1357. [CrossRef] [PubMed]

54. Puche-Sanz, I.; Alvarez-Cubero, M.J.; Pascual-Geler, M.; Rodríguez-Martínez, A.; Delgado-Rodríguez, M.; García-Puche, J.L.; Expósito, J.; Robles-Fernández, I.; Entrala-Bernal, C.; Lorente, J.A.; et al. A comprehensive study of circulating tumour cells at the moment of prostate cancer diagnosis: Biological and clinical implications of EGFR, AR and SNPs. Oncotarget 2017, 8, 70472-70480. [CrossRef] [PubMed]

55. Awe, J.A.; Saranchuk, J.; Drachenberg, D.; Mai, S. Filtration-based enrichment of circulating tumor cells from all prostate cancer risk groups. Urol. Oncol. 2017, 35, 300-309. [CrossRef] [PubMed]

56. Renier, C.; Pao, E.; Che, J.; Liu, H.E.; Lemaire, C.A.; Matsumoto, M.; Triboulet, M.; Srivinas, S.; Jeffrey, S.S.; Rettig, M.; et al. Label-free isolation of prostate circulating tumor cells using Vortex microfluidic technology. NPJ Precis. Oncol. 2017, 1, 15. [CrossRef]

57. Russo, G.I.; Bier, S.; Hennenlotter, J.; Beger, G.; Pavlenco, L.; van de Flierdt, J.; Hauch, S.; Maas, M.; Walz, S.; Rausch, S.; et al. Expression of tumour progression-associated genes in circulating tumour cells of patients at different stages of prostate cancer. BJU Int. 2018, 122, 152-159. [CrossRef] [PubMed]

58. Miyamoto, D.T.; Lee, R.J.; Kalinich, M.; LiCausi, J.A.; Zheng, Y.; Chen, T.; Milner, J.D.; Emmons, E.; Ho, U.; Broderick, K.; et al. An RNA-Based Digital Circulating Tumor Cell Signature Is Predictive of Drug Response and Early Dissemination in Prostate Cancer. Cancer Discov. 2018, 8, 288-303. [CrossRef]

59. Murray, N.P.; Aedo, S.; Fuentealba, C.; Reyes, E.; Minzer, S.; Salazar, A. The presence of secondary circulating prostate tumour cells determines the risk of biochemical relapse for patients with low- and intermediate-risk prostate cancer who are treated only with external radiotherapy. Ecancermedicalscience 2018, 12, 844. [CrossRef]

60. Bachman, J. Reverse-transcription PCR (RT-PCR). Methods Enzymol. 2013, 530, 67-74.

61. Pantel, K.; Denève, E.; Nocca, D.; Coffy, A.; Vendrell, J.-P.; Maudelonde, T.; Riethdorf, S.; Alix-Panabières, C. Circulating epithelial cells in patients with benign colon diseases. Clin. Chem. 2012, 58, 936-940. [CrossRef]

62. Poruk, K.E.; Valero, V.; He, J.; Ahuja, N.; Cameron, J.L.; Weiss, M.J.; Lennon, A.M.; Goggins, M.; Wood, L.D.; Wolfgang, C.L. Circulating Epithelial Cells in Intraductal Papillary Mucinous Neoplasms and Cystic Pancreatic Lesions. Pancreas 2017, 46, 943-947. [CrossRef] [PubMed]

63. NCI Dictionary of Cancer Terms. Available online: https://www.cancer.gov/publications/dictionaries/cancerterms (accessed on 31 May 2019).

64. FDA-NIH Biomarker Working Group. Understanding Prognostic versus Predictive Biomarkers; Food and Drug Administration (US): Silver Spring, MD, USA, 2016.

65. Scher, H.I.; Graf, R.P.; Schreiber, N.A.; McLaughlin, B.; Jendrisak, A.; Wang, Y.; Lee, J.; Greene, S.; Krupa, R.; Lu, D.; et al. Phenotypic Heterogeneity of Circulating Tumor Cells Informs Clinical Decisions between AR Signaling Inhibitors and Taxanes in Metastatic Prostate Cancer. Cancer Res. 2017, 77, 5687-5698. [CrossRef] [PubMed] 
66. Sciarra, A.; Gentilucci, A.; Silvestri, I.; Salciccia, S.; Cattarino, S.; Scarpa, S.; Gatto, A.; Frantellizzi, V.; Von Heland, M.; Ricciuti, G.P.; et al. Androgen receptor variant 7 (AR-V7) in sequencing therapeutic agents for castratrion resistant prostate cancer: A critical review. Medicine (Baltim.) 2019, 98, e15608. [CrossRef] [PubMed]

67. Miyamoto, D.T.; Ting, D.T.; Toner, M.; Maheswaran, S.; Haber, D.A. Single-Cell Analysis of Circulating Tumor Cells as a Window into Tumor Heterogeneity. Cold Spring Harb. Symp. Quant. Biol. 2016, 81, $269-274$. [CrossRef] [PubMed]

(C) 2019 by the authors. Licensee MDPI, Basel, Switzerland. This article is an open access article distributed under the terms and conditions of the Creative Commons Attribution (CC BY) license (http://creativecommons.org/licenses/by/4.0/). 